\title{
SIGNIFICANCE OF APPINITIC SUITE OCCURENCE IN TOCANTINS PROVINCE, CENTER OF BRAZIL.
}

\author{
AMANDA GRANJA LEITE ${ }^{1}$, REINHARDT ADOLFO \\ FUCK $^{2}$, ELTON LUIZ DANTAS SR. ${ }^{1}$ AND AMARILDO \\ SALINA RUIZ SR. ${ }^{3}$ \\ ${ }^{1}$ Universidade de Brasília \\ ${ }^{2}$ Universidade de Brasília (UnB) \\ ${ }^{3}$ Universidade Federal de Mato Grosso \\ Presenting Author: amandafgdleite@gmail.com
}

Appinitic rocks preserve evidence of mantle processes that can produce as end members voluminous late- to post-collisional granitoids by hybridization and fractionation mechanisms. The appinitic groups display dark color and are dominated by mafic to intermediate small bodies. In the boundary of Paraguay and Brasília belts, Tocantins Prrovince, central Brazil, the occurrence of a large granodiorite pluton and a small quartz monzodiorite stock with high $\mathrm{Ba}+\mathrm{Sr}$ contents $(\sim 3000 \mathrm{ppm})$ is described. The quartz monzodioritic stock shows dominance of hornblende phenocrysts as mafic mineral in a fine-grained matrix, calcalkaline signature and peripheric character. These features strongly suggest an association of appinitic rock. The stock is characterized by $\sim 56$ wt. $\% \mathrm{SiO}_{2}$, high $\mathrm{mg \#}(\sim 56)$, and relatively high Ni ( 115 ppm), V ( 163 ppm), and $\mathrm{Cr}(\sim 225 \mathrm{ppm})$ contents, which point to a mantle-derived signature for their parental source. The Harker diagrams pattern, the broadly parallel plots of chondrite-normalized elements and the $\mathrm{Nd}$ isotopic data provide strong evidence of cogeneticity with the plutonic high $\mathrm{Ba}-\mathrm{Sr}$ granodiorite. The investigated appinitic suite indicates a parental magma generated by partial melting of a thickened mafic lower crust with involvement of enriched mantle-derived appinitic magma. It is known that large amounts of high Ba-Sr magmatism can be produced as the result of late accretion or decompression in the final stages of continental arc evolution and leads to continental crustal growth. The geochemical data and negative $\varepsilon_{\mathrm{Nd}}(\mathrm{T})$ values (-6.47 and -6.65$)$ of the investigated rocks suggest an evolution from partial melt of mantle-derived magma previously metasomatized by subducted slab fluids. A model based on post-collisional lithospheric delamination is proposed, where slab breakoff and subsequent mantle upwelling led to partial melting of the enriched subcontinental lithospheric mantle beneath the continental crust. The high Ba-Sr suite characterize the Tocantins Province stabilization within Western Gondwana, which can be associated to the end phase of new closure stage (post ca. $600 \mathrm{Ma}$ ), related to the prolonged subduction of thick oceanic plateau/proto-crust (paleo Goiás Magmatic Arc) toward the Amazonian Craton. The appinitic suite record of one of the last tectonic events related to the Brasiliano-Pan-African Orogeny, leading to the cratonization of Gondwana. 